DOI: $10.1515 /$ hssr -2016-0023

\title{
Actors in Search of Theatre's Quintessence
}

Erica Letailleur*

Université Jean Moulin Lyon 3, France

\begin{abstract}
At the border between the fields of anthropology of theatre and phenomenology, this article presents and analyses the answers given by a sample of French theatre actors to an apparently simple question: How would you define your art? One could have been expect a wide range of answers, which would have reflected the infinite multiplicity of perspectives about that subject. Yet unexpectedly, the author deduces from the field investigation she conducted, a common and almost consensual vision of theatre expressed by these actors: an art in which practitioners are in the poetic quest of themselves, in their most accomplished humanity, in harmony with the self, the Other and the life (le vivant).
\end{abstract}

Keywords

Anthropology of theatre, phenomenology, poetics, language, aesthetics

For Professor Jacques Nichet, "no single form can define theatre, which continues to escape its own identity, from time immemorial" (Nichet, 1975: 2011). Of course, if we only care for the form, it is obvious that theatre is an imperceptible truth in its multiple aspects and universal by nature, as he says. Yet, let me ask one question: even if nowadays there is a multiplicity of forms identified in a more or less consensual way as theatre, how is it that we are able to qualify them precisely as "theatrical" or "non theatrical"? What makes something

* Centre Transdisciplinaire d'Epistémologie de la Littérature et des Arts Vivants (CTEL)Université de Nice Sophia Antipolis UFR Lettres Arts et Sciences Modernes, 98 boulevard Edouard Herriot, Nice; letailleure@gmail.com 
become theatre and why? Is an answer possible or even desirable?

This problematic has been widely explored in theatre studies literature and even in all works about theatre, one way or another. Far be it from me to propose again a new definition of theatre, or even my opinion on that question. In this article, I simply wish to draw attention to this definitional multiplicity and to the lack of understanding ensuing from it at practical level - notably for practitioners, and more so for actors. Of course, somehow, the answer depends on who is asking and who is answering, and a priori it could seem natural that an actor does not have the same answer as a curator or an academician, for example. But beside the issue of point of view, one could understand that practices suffer from the lack of a common or collective vision, leading, in a certain way, to what is generally qualified as a "crisis". Here, according to Pierre Bourdieu, the researcher's role should be precisely to try to contribute to a better take on hermeneutical thought, because neglecting the definition of a subject also means opening the door to ignorance:

"I will only ask why so many critics, so many writers, so many philosophers put so much complacency to profess that the experience of an art work is unspeakable, that it escapes rational knowledge by nature; why they hasten to claim without fighting the defeat of science; where their so powerful need to lower rational knowledge come from, where this fury to claim the irreducibility of an art work comes from..." (Bourdieu, 1992: 11).

To grasp all the strength of this assertion, it may be necessary to remember shortly the major strands of the analytical philosophy of art. At first, it seems essential to make a distinction between ontological reflexion and the "teleological vision of society," as Katia Légeret says (Légeret, 2001: 198). Theories of aesthetics according to which art could be definable seem deciduous by principle for certain thinkers, as Morris Weitz emphasizes (Weitz, 1956: 27-35). According to him, art cannot be defined since it has no sufficient intellectual properties (Danielle, 1985: 215). He proposes to consider the concept of art as "open" to new properties by principle, but as non-definable by nature (Danielle, 1985: 215). Later, George Dickie will refute this theory by offering the hypothesis of an "institutional" definition of art, according to which art's world (the social institution including at least 
artists, curators, art lovers, critics, historians, philosophers and any people acknowledging to be actively involved in art's world) is like a frame for the definition of practices, by the acceptance of conventions, and it allows to confer the status of art work to a tangible or intangible artefact (Danielle, 1985: 215).

There is, of course, a slight difference made by art philosophers between theories referring to classical art and those referring to contemporary art. In the same direction and by extension, there are nuances about divisions between fine arts and decorative arts. As for classical art, definitions, methods and aesthetic writings should be sufficient to give information on what it is by definition and on the role conferred to it in society, depending on space and time. The same holds true for decorative arts. Yet "contemporary art" and "fine arts", would escape more and more to rational understanding since minimalist and conceptual eras, with Malevitch's and Deschamps' works (Žižek, 2006: 116-117). Finally, such an approach leads to distinguishing, in the definition of art, a determining historicity, evolving towards a supreme individuality. The idea according to which a possible definition would no longer exist in contemporary art, because its variables would have become infinite in their forms, seems to find its roots in that thought. Isn't it to give to form the attributes of content? ${ }^{1}$ - This is an obvious confusion showing through all levels of the chain of creation. Yet, it is precisely on this confusion that theatre's perception lies on, for practitioners in general and artists in particular.

If these considerations may seem abstract, when confronted to the reality of the field and of practice, one immediately notices that they influence action directly, at several levels. Thus artists are often reticent to define their art from a practical as from an intellectual point of view, since it would seem to them like a hindrance to their creative liberty, irrational and individual by nature, according to most of them. Finally, to ask performing artists to define their art seems like the message of a constraint, the restriction of a practice which should never be delimited. Is it really the case?

In order to open these considerations regarding theatre in a concrete way, I conducted a field investigation with forty-six professional French theatre actors who took part in a lifelong training called "Autonomy of 
the Actor", implemented by Ayn Seyir centre in Paris, between 2006 and 2013. On the first day of each yearly session, I asked the participants what definition they were giving to their art.

This is about trying to give shape to a thought from the diffuse and common experience of a multitude - and despite the general disclaim of a definitional multiplicity of theatre, we will see that a certain consensus exists in the description of this art by the individuals I interviewed. And since thought makes possible the elaboration of knowledge, let's keep in mind what Bourdieu's philosophy inspires, for which it will be a duty for the researcher by profession, for the professional by necessity, and for the human by nature.

\section{The ideal of becoming "more human"}

In the words of the actors I met in the field, I noticed that they were having difficulties to define the art they had chosen as a profession. For example, some of them were reinterpreting the question I was asking them ("How would you define your art?") by trying to define art in general without targeting the peculiar performing art they were practicing. Others were raising the art they were practicing to the level of absolute and singular art. Thus, if some of my interlocutors were showing an obvious difficulty to delineate an answer axis, others were even claiming not to want or not to be able to do it - this is a common attitude I observed regularly with the artists I met over the years.

Without dwelling on their personal difficulties or the reasons which were making them think this way, I will give here an overview of the analysis I made from some of my interlocutors' words. For that, let's focus on three recurrent points I found in their answers: theatre defined in relationship with oneself, with the Other, and with life (le vivant).

\section{a. Being oneself, but another self}

In the approach to their art by these actors, one of the first things which stroke me is linked to the individual relationship every one of them was creating with theatre. For example, one of them said: "... with [theatre practice], I meet myself, but another side of myself." Another one said: "I'm doing it to be me, but not me...". And another actor expressed the same idea: "One can say 'me' or not, but it's always me...". 
And: "That is, we have a true intimate connexion. That's why I always tend to try not lying, to be [...] in harmony with myself". Another actress talked about the same idea with the following words:

"Theatre, in fact, is a research about me and the sense of my life. [...] This is something which refers me to myself, to my place in the world and also, which reflects me to the others. As sense is something one searches all along life, I think I am still searching my own definition of theatre, because I am looking for theatre's meaning. I look for it in my world's grasp and this is a reflexion about existence. This is abstract, but that's it. I think I will look for a definition all my life" (Letailleur, 2016).

Theatre as an art enabling the one practicing it to meet another "face of the self", of "oneself", the "self', seems to be a recurrent element in the answers given by the artists I met, to the question of the definition of theatre. Of course, from a general perspective, the actor's identity has been and is still largely discussed and analysed: who plays? Who's on the stage the character or the actor? What is the identity of the one who's talking? Etc. $^{2}$

Without entering such general considerations, let's focus one moment on what this attitude of the actors I met could signify, at different levels. It is obvious that it would be simplistic to understand their words literally, by thinking that these ones were only seeking to be in diverse situations, thanks to the roles they were playing. Maybe this aspect could be studied apart, from the psychoanalytical or psychological perspective, but that's not the point here. Such considerations would start from the presupposition that these talks are locked in their own contingences and even if it may be true from a certain point of view, that's not the question (these people could also have been able to "find themselves" by doing another job or art, if so). Let's suppose this is not the case and let's see what it echoes in the phenomenological area. In what aspects the actors' art would have the theoretical necessity to confront them to their self, how and why?

Arthur Rimbaud's approach of the "I is Somebody Else" ("Te est un autre") is not to be confused with Paul Ricoeur's thought of the "Oneself as Another" ("Soi-même comme un autre") (France Culture, 2012). 
According to Rimbaud, the $I$ is replaced by the Other, in a vector's situation whose self-identity is dispossessed by the inspiration process. Again, this is maybe the more conventional way to understand the actor's status, in theatre's reality. Yet, in the words of the actors I met, something else seems to be at stake, because these artists evoke the quest of their own self through theatre practice. In the end, this search for oneself would enable them to define the art they are practicing in an apparently judicious manner for themselves.

Thus, in Paul Ricoeur's thought (Ricoeur, 1990), it could be possible to draw a first strand of analysis of the actors' situation, regarding the relationship they have with identity search. Thus, it would be about distinguishing what is of the order of sameness and what is of the order of samehood in the actors' work, also in regard to the relationship of otherness they keep simultaneously in the dramatic action with the role, with the self and with the audience.

First, let's remember shortly that the concept of sameness is understood by Ricoeur as what is at the same time "unique and recurrent" in the individual (Ricoeur, idem). That is, the $I$ which is always the same, which is stable through time and change. Samehood, on the other hand, concerns individual identity, implying a devenir, a story to be told. Let's also remember that the concept of otherness is understood here at an intimate level, inside individuality itself, as it is also a part of it. Thus, let's try to draw a rough parallel with the actor (if I may be forgiven): sameness could be defined as the being of the person independently of artistic practice, samehood could be defined as the being of the artist on the professional path, as for otherness, it could be observed through the different roles or projects actors represent during their life.

In Paul Ricoeur's philosophy, identity is built through a story, because the individual needs to go through the Other to explore one's own identity, whose expressions are numerous - and far more complex than the ones of embodied identity. Thus, the actors' status would be built on an artistic path composed by several roles (whose nature may be constant or changing according to forms) through which one's own identity is explored in its multiple expressions. That is about moving the I perspective, in order to include the Other to better understand the self. The story/theatrical career, by enabling this, is like some kind of 
experience and thought laboratory, which allows a person to be inside reality and to conceive his/her life project. It allows, thus, to confront the dispersion of oneself in samehood: that is what Ricoeur calls the "synthesis of the heterogeneous" (Ricoeur, 1990) or, to put it in other words, as Camille Riquier suggests: the "unity of the multiplicity" (France Culture, 2012). Here, the unchanging is the consciousness including the body, the Other, and the relationship with the self in a totality. In synthesis, this way of thinking seems proper to the idea of theatre evoked in the words of the actors I met.

Moreover, the words "unity of the multiplicity" refer to a concept coming from Eastern philosophy - much developed by Sufi philosophers (Letailleur, 2009) on the topic of Vahdet-i Vücud (lit. "unity of the existence", Seratli, 2006). Shortly, the concept could be presented as the absolute unity at the origin of existence, which takes shape under the aspect of the multiplicity of everything existing, that is, everything existing in the multiplicity of phenomena is only the expression of the absolute unity (Cebecioglu, pp.681-682, 2004). If the words of the actors I have interviewed could be reinterpreted in that sense, it would be for the actors about searching the self, not as individuals but as an expression of the absolute $I$, which is not and never will be theirs, but which is them anyway and transcends absolutely their individual me. The Turkish poet Yunus Emre puts it this way:

"I don't say me, I am not in me

There is an I in me, inside me" (Gölpınarl, 2003).

Here, it is only about showing how much what could seem confused and even naïve at first in the words of the actors I met is, indeed, very significant of a state that is fundamentally necessary to theatre, but generally avoided by the general discourses about $\mathrm{it}^{3}$ : transcendence, literally. That is, the art of theatre is hardly conceivable apart from a transcendental, sacred thought, in view of the actors' testimonies I collected in the field.

Thus, when one of these actresses I met said: "It is not art nor crafts which makes an actor", it also evokes this reflexion. The art of the actor has the necessary specificity to confront the self, because this is also a 
human realization path (at the phenomenological, esoteric and transcendental levels), since it weaves the story of the being, of the artist and of the roles, both in crossed and reflecting ways, to the point they all merge. That way, the symbolic function of theatre is expressed, at first, in the relationship that actors keep with professional practice (in an almost votive sense) and in the way they define it.

\section{b. Different alterities}

The second element seeming to define theatre in its necessary aspects, for the actors I interviewed, is about the notion of alterity and more precisely, about what it involves at the collective level. Let's see a few extracts, to figure out some of the aspects of this analytical strand. For example, an actress said: “. . a at first, this is about questioning people. There is the audience. That is, questioning people through the story, through a character." Later, she also said: "This person receives, without the look of the others, without being judged, without the look of the mass around, without having the feeling to be melted in the mass". And finally: "This is a team work. [...] If there hadn't been the others, I don't think I would have chosen this job. The others make me think of family and of the notion of character. The character is also an Other. I meet the Other through the character and through the story." Another actor that I met said: "Yes, that's it: the gift of oneself and of what surrounds us, for the others, with the others, to reveal what is maybe hidden, buried, but so present...". Amongst the other testimonies I gathered all years long, words like "collective", "audience", "team", "transmission", "exchange", communication", "communion", are recurrent. To give a last example, another actress said:

"For me, theatre is in the public interest. It gives people the opportunity to look at themselves. It's a start. At least, they observe themselves like in a mirror, with all that is good and bad. It makes possible the fact that they manage to look at themselves, by [...] this exchange between actors [...] and the audience." (Letailleur, 2016).

As it is easy to notice, obvious links appear between the relationship that the interviewed actors say they have with theatre considered in the 
search of the me perspective, and theatre considered in connection to the Other and to the group. Notably, regarding the "mirror effect" between the me in the scope of samehood and otherness, and between the actor as an individual and the collective. The latter can be considered from the testimonies I gathered in three different categories: collective reference to the audience, collective reference to the artistic team, and collective reference to the multiplicity of characters that actors play during their career. Here, the collective refers, of course, to another face of alterity.

First, let's consider the paradigm as it is described by the actors I met, from the perspective of its relationship to character. Character represents an Other which, even if it is fictitious, becomes tangible from the moment that it is embodied by the actor, who lends it his face, to paraphrase Emmanuel Levinas (Levinas, 1990). This is what could be considered as the nuclear figure of alterity, which evokes an other self, as it has been described by Ricoeur (Ricoeur, 1990). This perspective itself refers at first, inevitably, to Denis Diderot's paradox (Diderot, 1994), because it recalls the status of the actors facing the character they play: at the same time being another and themselves, without merging them. It asks from the actors, as Diderot says, a fortitude enabling them to feign the emotions of the character without feeling them for real: "[The actor] is a mirror always open to show the objects and to show them with the same precision, the same strength and the same truth" (Diderot, 1994). He also says: "Being sensitive is one thing, feeling is another thing. One of them is a matter of soul, the other is a matter of judgement." (Diderot, 1994).

In more recent times and at a different level, Emmanuel Levinas' philosophy recalls the necessary opposition between sense and feeling, in this perspective. Sense refers to the human ability to be moved; as for feeling, it is a phenomenon by which a stimulus provokes a reaction producing a perception. In the frame of the encounter with the Other, Levinas insists on the double sense provoked by the apparition of the Other's face, which is "the emergency of the unimpeachable necessity of my responsibility to help, to listen and to know the Other" (Salanskis, 2012). This is what Levinas calls the "intrigue of ethics" (Levinas, 1990), according to which human beings learn the signification of morals by being able to recognize the despair and the teachings from the Other. 
When this philosophical theory is confronted with the analysis of the art of theatre, it seems to raise two fundamental reflexion strands:

1. The actors playing a character meet this imaginary Other, in the process of embodiment. By doing so, they necessarily put themselves in the emergency situation described by Levinas in the intrigue of ethics, in a fictive and intimate manner. It refers to alterity of the self described above.

2. The actors playing a character become the face of an Other set as an example to meet the collective (partners and audience), in a fictitious situation in which the necessary emergency described by Levinas in the intrigue of ethics takes shape. This will make the collective responsible for helping (in an imaginative manner), and listening to teachings.

Thus, the encounter between the actors and the Other as an imagined alterity occurs as soon as they are confronted with the role's fiction, and as soon as they encounter the Other as a physical alterity, initially in the relationship they have with the members of the team they work with, so as to form a whole: a group leading a collective artistic project. Thus, the ideas of family, of sports team are regularly mentioned in the testimonies I gathered, as in general literature on theatre, to evoke the idea of membership to an artistic team, to a collective body.

In the same breath, alterity is considered in the frame of a relationship to the collective, towards the audience (Rubym, 2012 and Mervant-Roux, 1998). On that subject, an actress I met emphasized what she called "a unique spectator" that is, the individual who is not framed inside the "mass", as she says. In this connexion, the famous French actor Laurent Terzieff says:

“... the irreplaceable specificity of theatre, is that it is a collectively lived experience. And before all, this is thanks to the real physical presence of the actors on the stage, which makes the audience become itself an extremely vivid group - I would even say a plural unicity, but not like a lonely crowd..." (Terzieff, 2010).

In these talks, one can also recognize the will Jerzy Grotowski had to rename audience as "the Spectator" (Grotowski, 2009): not unique as an individual but as a transcendent and absolute group, with which a true 
"communion" is lived. Communion means for these actors, to live literally a strong, performative and collective meta-daily experience.

Thus, the actors I interviewed seem to agree, in their artistic practice, about the major importance of the relationship with an audience that is aware of the teaching they are representing, as incarnations of the Other, and also with an absolute audience Terzieff names, as quoted above, a "plural unicity" - a phrase recalling the "unity of the multiplicity" evoked above. Of course, it takes shape at a different level here: individuals are united in an entity which both overwhelms and includes them, generally called "the audience" (or "spectator"), alternately as a phenomenal, social and even transcendental entity.

This phenomenon is named, in Sufi teachings "Tevbid", that is, the absolute unity's principle (Letailleur, 2010). In numerous rituals, it is also a specific part during which all the members of the assembly are considered as united in an absolute manner. That is, in the perspective of the union of the creatures with their creator, outside the creation. And when the metaphor of actors reflecting the Others like a mirror (largely used in epistemological literature on theatre since Diderot's work), is considered in the scope of this unicity principle, it recalls another Sufist metaphor: the one of the broken mirror, in which each piece reflects the same thing (Rumi, 1988).

Finally, theatre in the eyes of the actors I met is the expressed manifestation of an alterity, which is necessary at several levels: the nuclear alterity of the individual, the alterity of the group considered as a collective body, and the alterity of the collective - paradoxically referring to an absolute "plural unicity", which is itself teaching, reflecting and transcending.

\section{c. Theatre in the scope of life and vice-versa}

The actors I interviewed also have a strong tendency to define their art in relationship with life. For example, one of them said: "I am doing theatre because I didn't find another way, another place, where I was able to find the human so much. To find the human means in all its vivid faces." Another said: "I don't really know what is art. I think it may be a quality hidden in every human being. If it's true, then, for me, it is about searching life in humanity." And another even insisted on the moving 
relationship between art and life: "It is very essential that, between art and life, a movement exists. A movement. That's necessary: a confusion, not to say a confrontation. That is, a moving threshold." Another said he had chosen theatre "in order for the others to go through [him]. Not only the other humans, but also the environment. Everything existing, everything living, everything living in the environment." Another actress said:

"For the last question, Madam: what is my definition of the art I practice? This is not simple! How could I answer? From the Dictionary's perspective, or the definition of... I mean... is it even possible to give a definition of that? - Personally, I have difficulty to give a definition. Life is something... At the same time, art is undefinable and for me, theatre is of the order of passion: the passion of life... To give the definition of a passion: it eats at you! You need it in order to live." (Letailleur, 2016)

Isolated from the whole speech, these words look a little confusing and even absurd. In the meantime, it is important to notice that they are also complex to decode, because they are made far from any intellectual or critical references. In spite of differences in the vocabulary used by these actors ("vivid faces of human", "life in human", "life", "everything living in the environment", "to live"), an important poetics of life seems to appear here. What is "life" in the words of these actors? And what is its relationship with theatre art itself?

Let's remember that the usage in French of the word "living" (le vivant), to qualify a category of performing arts is quite new and borrowed from the administrative vocabulary (Triffaux, 2012). Life (le vivant) in theatre has been, notably, largely analysed by Jean-Pierre Triffaux, in several works. It enables to make a distinction between what is generally defined in the show and the performance in opposition with mechanics. On the other hand, some researchers think this paradigm in opposition with death. There is a third perspective always quoted but never deeply analysed in literature on theatre - except in Antonin Artaud's work: the metaphysical point of view. Let's try to develop shortly these different strands, in order to better identify to which synthetic thought the words of the actors I interviewed could refer. 
The first point to be discussed is related to life in opposition with mechanics or technology, as there is in cinema, digital arts or even fine arts, at different levels. The peculiarity of "vivid art" (spectacle vivant) is that it puts bodies in action bic et nunc - this is true for all performing arts understood in this perspective: theatre, dance, music, circus, opera, performance, etc. This is what Yves Lorelle expressed this way: "Vivid art (le spectacle vivant) is a 4D imaging, or in other words, a space crowded with imaging bodies" (Lorelle, 2003: 35). As for Jean-Pierre Triffaux, he recalls the concordance of this understanding of life with biology, leading to thinking of its relationship with performing arts in terms of energy (energy of life, "strength enabling to built artistic materials, to give them power, to make them work", Triffaux, 2012). From this link between biotic life and performing arts, Triffaux identifies what he names the "artistic life", in order to mark the difference with biological life:

"Thus, artistic life is understood both as what is lived from a real experience, shared by human beings together, in the flesh and in life, both because life results from a psycho-chemical exchange part between biological elements, and from an artificial communication and noncommunication process - some kind of internal watchmaking of an artistic nature's microscopic elements." (Triffaux, 2012)

According to critical vitalism (Worms, 2015: 15-19), life can always be understood between the two extremes that are the bio-chemical mechanisms which compose it, and the subjective experience linked to something else than itself. Thus, according to Henri Bergson's creative evolution theory (Bergson, 2007), the subject of the philosophy of life would be to stand between this movement of life and what is opposed to it in its destruction - that is, illness, death.

Here comes the second reflexion strand, in the sense that the words of the actress I interviewed and who was defining the relationship between theatre and life as a "moving threshold", could be understood. Her thought recalls a word said by Tadeusz Kantor in Theatre of Death, about "this gate which cannot be crossed", at the threshold of which, according to the metaphor he utilizes, the original actor (the first one) would have stood, between life and death, between dream and 
awakeness (Kantor, 1977: 215-224). From this perspective, theatre could symbolize, in a tangible manner, this sort of inbetweeness - even if it is important to remember here, that life is not understood in its opposition with death, but in a movement of tension "between normal and pathological" (Worms, 2015: 15-19): that is, life contains death and viceversa.

At the same time, the consideration of life in this necessary tensed relationship leads to a larger vision, which is the one formulated by Gilles Deleuze in the name of vitalism: "the power of non organic life" (Deleuze, 2006), in other words: life understood as a necessary and immanent strength going through the multiplicity of single existences. Maybe this point makes possible the understanding of the ideas the actors I met tried to express, when talking about life in the buman they try to grasp through theatrical experience, in some way. It could be understood as this power going beyond simple ephemeral organicity. Moreover, this is the deadly organicity point, referring to morbidity, that Antonin Artaud vehemently denounces, in the Western apprehension of theatre and culture. He says that it "[stinks] human unbelievably, the temporary and tangible human, I would even say the human-carcass" (Artaud, 1935: 528). At the same time, life's strength appears both as an irrepressible need and as what moves transcended humanity:

"We all need to live and to believe in what makes us live, and that something makes us live, - and what comes out from the mysterious inside of ourselves, doesn't have to come back perpetually on ourselves for the coarsely digestive sake.

I mean that if we are all concerned about eating at once, we are even more concerned about not wasting, for the sole sake of eating at once, our simple strength of being hungry" (Artaud, 1935: 505).

Antonin Artaud makes a fundamental distinction between the human considered from the perspective of organic and biological matter, and the human considered from the point of view of what overwhelms and makes life - in other words: what makes the human to be transcended. In this relationship, it seems almost obvious that the actors from whom I gathered testimonies yearn more to discover this second aspect of the 
human than the first. They never mentioned any material and physical elements of what they were calling "life" and "living" - even if it could have been easier for them to do so. In contrast, the confession some of them made about their difficulty or even impossibility to express the essence of what they wanted to say, could be interpreted as the difficulty or the impossibility to express this irreducible and transcendent aspect of the "life power" inside the human, so to speak.

Thus, it seems particularly important to remember that in their approach to theatre, as an art of the life of human beings, these actors do not seek only the signs of what makes life in its tangible and singular aspects, the biological characteristics of theatre as a formal and symbolic representation of life, but also and above all, the common and manifest immanent strength of all humans, which makes them exist in the tension between the singularity and the whole, as well as between the being and the non-being.

In conclusion, a specific "composite sketch" of the theatre seen by the actors I met in the field takes shape, here. This theatre, in synthesis, is like a path requiring from them to realize themselves in a human perspective, in order to become a potential receptacle for the representation of the Other to others, at a transcendental and symbolic level, at the threshold of life and embedded in the necessary being of the human. This is a professional theatre, understood in its almost votive meaning. Of course, this cannot be considered as a definition, because this assertion only takes into account some aspects of theatre from the point of view of the French actors I interviewed during my field investigation. Yet, this is the basis defining what I call the actor's poetics path (Letailleur, 2016).

As one of the actresses that I met said, maybe theatre is in fact as irreducible as life itself. This never stopped humans from questioning what it is, and I believe it cannot and must not hinder the search for an even partial understanding, because the subject is complex. Moreover, some words by Béatrice Bonhomme about poetry could totally fit this way of understanding theatre, for the actors I interviewed:

"Poetry is a vertical language aiming to go through the human from top to bottom and from the bottom up - the human and the universe. The poet's 
HSS, vol. V, no. 3(2016): 59-76

work is about settling, in order to cross the thickness of things. It is important, thanks to a long quest, a long search, to manage crossing, in order to find the word, the sense, the original signs, the meaning. Spiritual belief in a hidden reality we are guessing, and we need to find under the envelop, the cover, the external surface of things, by a diving, a quest in secret depths. Poetry carries simultaneously the secret of the human and the secret of the universe" (Bonhomme, 2015: 286).

Maybe so is theatre.

\section{References}

Aslan, O. (2005). L'Acteur au XX $X^{i m e}$ siècle, éthique et technique. Vic la Gardiole : L'Entretemps.

Artaud, A. (1935). "La mise en scène et la métaphysique", in Le Théatre et son double. Paris: Gallimard.

Bergson, H. (2007). L'Evolution créatrice. Paris : PUF.

Bonhomme, B. (2015). "Salah Stétié ou l'espace poétique d'une méditation”, in La Poésie comme un espace méditatif?. ed. Béatrice Bonhomme and Gabriel Grossi. Paris : Classiques Garnier, Série Rencontres. n¹04.

Bourdieu, P. (1992). Les Règles de l'art. Genèse et structure du champ littéraire. Paris : Editions du Seuil.

Cebecioğlu, E. (ed.) (2004). Tasavvuf Terimleri ve Deyimleri Söəlïğ̈̈. Instanbul : Ağaç Kitapevi Yayınları.

Danielle, L. (1985). "Philosophie analytique et définition de l'art". Revue philosophique de Louvain, quatrième série. t. 83 n58.

Diderot, D. (1994). Le Paradoxe sur le comédien. Paris : Gallimard.

Dusigne, J.-F. (2008). L'Acteur naissant. La passion du jeu. Montreuil sous Bois : Editions Théâtrales.

Duvignaud, J. (1993). L'Acteur. Paris : Gallimard, NRF.

Gölpınarlı, A. (2003). Yunus Emre, Divan ve Risaletü'n-Nubsiyye. İstanbul : DER Yayınları.

Grotowski, J. (2009). La Ligne organique au théatre et dans le rituel. Houilles : Le Livre qui Parle, Houilles.

Kantor, T. (1977). "Le théâtre de la mort". in Le Théatre de la mort. Paris : L'Age d'Homme.

Legendre, P. (1978). La Passion d'être un autre. Etude pour la danse. Paris : Editions du Seuil.

Légeret, K. (2001). Esthétique de la danse sacrée. Inde traditionnelle et art contemporain. 
HSS, vol. V, no. 3(2016): 59-76

Paris : Geuthner.

Letailleur, E. (2010). La Cérémonie du Ayn-i Cem des Alevis d'Anatolie mise en scène, du contenu intersymbolique au discours méta-cultu( $r$ el. Munich : EUE.

Levinas, E. (1990). Autrement qu'être ou au-delà de l'essence. Paris : Le Livre de Poche.

Lorelle, Y. (2003). Le Corps, les rites, la scène, des origines an XXème siècle. Paris : Les Editions de l'Amandier.

Mervan-Roux, M.-M. (1998). L'Assise du théâtre. Pour une étude du spectateur. Paris : Editions du CNRS.

Miquel, J.-P. (1996). Le Théâtre des acteurs. Paris : Flammarion.

Namiand, Arlette (ed.), L'Acteur : des héros fragiles, Autrement, Paris, 1985.

Nichet, J. (2011). Le théatre n'existe pas. Lecon inangurale prononcée le jeudi 11 mars 2010. Chaire de création artistique 2009-2010. Collège de France. 2011.

Pavis, P. (texts gathered by) (1993). Théories de l'acteur, de Stanislavski à Barba, University of Paris 8 Saint-Denis.

Rabanel (alias J.-P Triffaux). (2014). Théâtrologies/2, l'art du dialogue. Paris : L'Harmattan.

Rabanel (alias J.-P. Triffaux). (2014). L'Interdiction du théâtre. Eloge du dialogue et du vivant. Sampzon : Editions Delatour France.

Ricoeur, P. (1990). Soi-même comme un autre. Paris : Editions du Seuil.

Rubym, C. (2012). La Figure du spectateur. Éléments d'bistoire culturelle européenne. Paris : Armand Colin.

Rumi, D. al-Din (1988). Le Mesnevi. 150 contes soufis. trad. Eva de VitrayMeyerovitch. Paris : Albin Michel.

Seratl, T. G. (2006). Vabdet-i V ücud ve Tevbid. Ankara : Furkan Yayınları.

Terzieff, L. (2010). in Fictions, à voix nues radio programme, France Culture. 09/07/2010.

Triffaux, J.-P. (2012). "Spectacle et vivant". video-conference broadcasted during Owverture vers les traditions théatrales de l'Orient. Institut Français. Ankara. $27 / 01 / 2012$.

Van Reith, A. and P. Petit (dir.) (2012). "L'Autre (3/4): Paul Ricoeur, soimême comme un autre", in Les nouveaux Chemins de la connaissance radio programme, France Culture, 05/12/2012.

Weitz, M. (1956). "The role of theory in aesthetics". The Journal of Aesthetics and Art Criticism. XV. 27-35.

Worms, F. (2015). "Pour un vitalisme critique". Esprit, n¹/2015 (January).

Žižek, S. (2006). La Subjectivité à venir. Paris: Flammarion. 
HSS, vol. V, no. 3(2016): 59-76

${ }^{1}$ All the more since the meaning of the word "aesthetics" in performing arts should be understood, as Katia Légeret argues, "according to the Ancient Greek meaning of aesthesis: it implies the research of the art work's sensitive appearance conditions, in which theory is never distinguished from practice" (Légeret, p.25, 2001).

2 There are many references about these questions, and notably amongst French theatre researchers, we could quote the works of: Aslan, 2005; Dusigne, 2008; Duvignaud, 1993; Legendre, 1978; Miquel, 1996; Namiand, 1985; Pavis, 1993.

3 This is only a general observation, which does not include peculiar approaches of individuals like Paul Claudel, Antonin Artaud or Jerzy Grotowski, for example.

\section{Biographical note}

Erica Letailleur is a Doctor in Theatre Studies (graduated from Nice Sophia Antipolis University), she specialized in the relationship between theory and practice in theatre. She received a transdisciplinary education, as an ethnologist and musicologist, and graduated from EHESS and from Paris Sorbonne University. She is also an actress and the general manager of international projects for IDEOGRAM Arts theatre company. 